\title{
Pembelajaran Pendidikan Anak Usia Dini Online di Era Pandemi Covid-19
}

\author{
Yusi Srihartini, Maulidia Pratami Lestari \\ Fakultas Tarbiyah IAI Nasional Laa Roiba Bogor \\ yusisrihartini5@gmail.com
}

\begin{abstract}
The online learning system is a solution for the teaching and learning process during the Covid-19 pandemic for all levels of education including early childhood education (PAUD). The research objectives were to obtain an overview of the effectiveness of online learning at the Early Childhood Education (PAUD) level, explain the obstacles and solutions for early childhood teachers in providing online learning, and explain the efforts of teachers in developing early childhood learning in the Covid region. The research subjects were four educators in two Raudhatul Athfal, leuwiliang-bogor sub-districts. Qualitative research design using interview techniques in collecting data. The results showed that the teaching and learning process was carried out online / online even though the learning was not effective due to obstacles including the lack of student motivation and lack of facilities such as cellphones and internet quotas. One solution is offline learning. Pay attention to the aspects of learning as a teacher's effort to achieve learning.
\end{abstract}

Key words: Effectiveness, Early Childhood Education Learning, Online

\begin{abstract}
ABSTRAK
Sistem pembelajaran online menjadi solusi proses belajar mengajar dimasa pandemi covid-19 untuk semua jenjang pendidikan termasuk pendidikan anak usia dini (PAUD). Tujuan penelitian adalah untuk memperoleh gambaran mengenai efektivitas belajar online ditingkat Pendidikan Anak Usia Dini (PAUD), Menjelaskan kendala dan solusi guru PAUD dalam memberikan pembelajaran secara online, dan Menjelaskan Upaya guru dalam mengembangkan pembelajaran PAUD diEra Covid. Subjek penelitian adalah empat orang pendidik di dua Raudhatul Athfal kecamatan leuwiliang-bogor. Design penelitian kualitatif dengan menggunakan teknik wawancara dalam mengumpulkan data. Hasil penelitian menunjukan bahwa proses belajar mengajar dilakukan secara online/daring walaupun pembelajaran
\end{abstract}


menjadi tidak efektif karena adanya kendala diantaranya kurangnya motivasi belajar siswa dan kurangnya fasilitas seperti handphone dan kuota internet. Salah satu solusinya adalah pembelajaran luring. Memperhatikan aspek pembelajaran sebagai upaya guru untuk mencapai pembelajaran.

Kata kunci : Efektifitas, pembelajaran pendidikan anak usia dini, online

\section{PENDAHULUAN}

Pembelajaran anak usia dini adalah kegiatan pembelajaran yang ditujukan pada anak usia dini yang memberikan pengalaman belajar melalui bermain, mencari pengetahuan sesuai kemampuan dan memberikan perbendaharaan kata pada anak. Masa anak usia dini sering disebut dengan golden age atau masa emas anak pada usia 0-5 tahun. Pada fase inilah pertumbuhan dan perkembangan anak sangat pesat sehingga naluri, kecerdasan intelektual, Kecerdasan emosional, kecerdasan spiritual dan karakter anak akan dengan mudah terbentuk sesuai dengan tingkat pertumbuhan dan perkembangan anak.

Pendidikan anak di usia dini dapat mengoptimallkan kemampuan dasar anak dalam menerima proses pendidikan awal sebelum melanjutkan pendidikan kejenjang selanjutnya. Pada pasal 28 Undang-undang Nomor 20 tahun 2003 tentang sistem pendidikan Nasional, pendidikan anak usia dini telah ditempatkan sejajar dengan pendidikan lainnya. Bahkan pada puncak acara Peringatan Hari Anak Nasional tanggal 23 juli 2003, Presiden Republik Indonesia telah mencanangkan pelaksanaan pendidikan anak usia dini diseluruh Indonesia demi kepentingan terbaik anak Indonesia.

Berdasarkan Undang-undang diatas, lembaga pendidikan anak usia dini menjadi salah satu sekolah yang memberikan pembelajaran kepada anak untuk meningkatkan kemampuan anak baik dibidang kognitif, afektif dan psikomotorik melalui pengalaman belajar anak. Anak dilatih untuk mematuhi tata tertib sekolah, mengenal proses belajar, dan berinteraksi dengan sesama.

Pada dasarnya, Tujuan sekolah sebagai bagian dari tujuan pendidikan nasional yaitu meningkatkan kecerdasan, 
Tarbiatuna, Vol. 1, No. 1, April 2021

pengetahuan, kepribadian, akhlak mulia, serta keterampilan untuk hidup mandiri dan mengikuti pendidikan lebih lanjut.

Akhir-akhir ini, Badan Kesehatan Dunia (WHO) menetapkan status pandemi virus corona (Covid-19). Status pandemi diputuskan karena dampak dan penyebaran Virus yang terdeteksi awal di Wuhan,China, itu telah berdampak keseluruh dunia (CNNIndonesia.com, Jakarta, 16 Maret 2020).

Usaha Pemerintah dalam mencegah penyebaran wabah Virus corona (Covid-19), Kementrian Pendidikan dan Kebudayaan (Kemendikbud) menerbitkan beberapa surat edaran terkait pencegahan dan penanganan Covid-19. Pertama, Surat edaran Nomor 2 Tahun 2020 tentang pencegahan dan penanganan Covid-19 di Lingkungan Kemendikbud. Kedua, Surat edaran Nomor 3 Tahun 2020 Tentang Pencegahan Covid-19 pada Satuan Pendidikan. Ketiga, Surat Edaran Nomor 4 Tahun 2020 tentang Pelaksanaan kebijakan Pendidikan dalam Masa Darurat Penyebaran Coronavirus Disease (Covid19) yang antara lain memuat arahan tentang Proses belajar dari rumah.
Dirjen PAUD Dikdasmen Kemendikbud, Harris Iskandar menjelaskan bahwa guru tidak harus terpaku pada pembelajaran daring dan pemberian tugas (CNN Indonesia.com, 31 Maret 2020). Walaupun pembelajaran dilakukan secara daring/online, guru diharapkan dapat mengembangkan kreativitas dan inovasi dalam memberikan pembelajaran yang menyenangkan melalui media teknologi. Menurut Chodzirin (2016) seperti ditulis Febrialismanto, Guru harus mengubah cara pandang dalam pembelajaran yang awalnya dari konvensional menjadi moderen. Kehadiran teknologi dalam pembelajaran merupakan suatu hal yang tidak dapat dihindari sehingga harus mempersiapkan diri untuk dapat memanfaatkan teknologi dalam pembelajaran. Pembelajaran dengan memanfaatkan teknologi memberikan daya tarik bagi anak untuk termotivasi dalam pembelajaran (Febrialismanto, 2020).

Media online diharapkan dapat memberikan feedback positif terhadap kegiatan pembelajaran secara online/daring. Dalam kondisi apapun, pembelajaran harus tetap dilaksanakan 
Tarbiatuna, Vol. 1, No. 1, April 2021

guna mencapai tujuan pendidikan bagi anak usia dini dalam mengembangkan wawasan anak dalam pembelajaran.

\section{Undang-undang Republik} Indonesia Nomor 20 Tahun 2003 Tentang sistem Pendidikan Nasional pada Pasal 1 ayat 15, menyatakan Pendidikan jarak jauh adalah pendidikan yang peserta didiknya terpisah dari pendidik dan pembelajarannya mnggunakan berbagai sumber belajar melalui teknologi komunikasi, informasi dan media lainnya (Undang-undang Republik Indonesia No.20 Tahun 2003).

Proses pembelajaran anak juga diharapkan akan selalu membuat anak mengingat sekolah mereka melalui aktivitas pembelajarannya. Guru sebagai penanggungjawab proses kegiatan pembelajaran harus mampu mengkontrol perkembangan anak Ketika aktivitas pembelajaran diterapkan di rumah sehingga nantinya setiap anak tetap mendapatkan catatan dari perkembangannya (Khirjan Nahdi, Sandy Ramdhani, Riyana Rizki Yulianti dan Yul Alfian Hadi)

Kondisi pandemi yang mengharuskan kegiatan belajar mengajar dilakukan dirumah inilah yang menjadi dasar tujuan penelitian.Penelitian ini bertujuan untuk 1. Menjelaskan efektivitas belajar online ditingkat Pendidikan Anak Usia Dini (PAUD), 2. Menjelaskan kendala dan solusi guru PAUD dalam memberikan pembelajaran secara online 3, Menjelaskan Upaya guru dalam mengembangkan pembelajaran PAUD diEra Covid.

\section{TINJAUAN TEORI}

Menurut Supardi (2013) seperti ditulis Afifatu Rohmawati pembelajaran efektif adalah kombinasi yang tersusun meliputi manusiawi, material, fasilitas, perlengkapan dan prosedur diarahkan untuk mengubah perilaku siswa ke arah yang positif dan lebih baik sesuai dengan potensi dan perbedaan yang dimiliki siswa untuk mencapai tujuan pembelajaran yang telah ditetapkan. Hamalik (2001) menyatakan bahwa pembelajaran yang efektif adalah pembelajaran yang menyediakan kesempatan belajar sendiri atau melakukan aktivitas seluas-luasnya kepada siswa untuk belajar. Efektivitas pembelajaran adalah ukuran keberhasilan dari suatu proses interaksi antar siswa 
Tarbiatuna, Vol. 1, No. 1, April 2021

maupun antara siswa dengan guru dalam situasi edukatif untuk mencapai tujuan pembelajaran. Efektivitas pembelajaran dapat dilihat dari aktivitas siswa selama pembelajaran berlangsung, respon siswa terhadap pembelajaran dan penguasaan konsep siswa. Untuk mencapai suatu konsep pembelajaran yang efektif dan efisien perlu adanya hubungan timbal balik antara siswa dan guru untuk mencapai suatu tujuan secara bersama, selain itu juga harus disesuaikan dengan kondisi lingkungan sekolah, sarana dan prasarana, serta media pembelajaran yang dibutuhkan untuk membantu tercapainya seluruh aspek perkem-bangan siswa. Efektivitas pem-belajaran merupakan suatu ukuran keberhasilan dari proses interaksi dalam situasi edukatif untuk mencapai tujuan pembelajaran. Dilihat dari aktivitas selama pembelajaran, respon dan pengu-asaan konsep (Afifatu Rohmawati, 2015).

Selama masa pandemi COVID-19 mengharuskan setiap satuan pendidikan menggunakan pembelajaran jarak jauh, itu menjadi satu satunya cara agar proses pembelajaran dapat terus berjalan, penggunaan media pembelajaran dan kreatifitas didalamnya menjadi titik kunci keberhasilan pembelajaran, namun kendala baik dari sistem media maupun dari kesiapan pengajar dan pembelajar akan menghambat kegiatan pembelajaran, hal tersebut menjadi kekurangan dalam pelaksanaan pendidikan jarak jauh/ Distance Education yang masih harus dibenahi untuk kedepannya (Reza Aprilianto Mandala Putra, 2020)

Salah satu bentuk pembelajaran alternatif yang dapat dilaksanakan selama masa darurat Covid-19 adalah pembelajaran secara online. Menurut Moore, Dickson-Deane, \& Galyen (2011) Seperti ditulis Firman dan Sri Rahayu Rahman, Pembelajaran online merupakan pembelajaran yang menggunakan jaringan internet dengan aksesibilitas, konektivitas, fleksibilitas, dan kemampuan untuk memunculkan berbagai jenis interaksi pembelajaran (Firman dan Sri Rahayu Rahman, 2020). Menurut Gikas \& Grant (2013) Pembelajaran online pada pelaksanaannya membutuhkan dukungan perangkat-perangkat mobile seperti telepon pintar, tablet dan laptop yang dapat digunakan untuk mengakses informasi dimana saja dan kapan saja. Menurut Korucu \& Alkan ( 2011). Penggunaan teknologi mobile memiliki 
kontribusi besar di dunia pendidikan, termasuk di dalamnya adalah pencapaian tujuan pembelajaran jarak jauh (Firman dan Sri Rahayu Rahman, 2020).

Menurut Moore, Dickson-Deane, \& Galyen (2011) seperti ditulis oleh Ali Sadikin, Pembelajaran daring merupakan pembelajaran yang menggunakan jaringan internet dengan aksesibilitas, konektivitas, fleksibilitas, dan kemampuan untuk memunculkan berbagai jenis interaksi pembelajaran (Ali Sadikin, 2020).

Menurut Nurmukhametov et al., (2015) Seperti ditulis Reza Aprilianto Mandala Putra, Penggunaan media internet/ elearning memiliki kendala yang cukup besar, koneksi jaringan dan kesalahan teknis seperti server down and error menghambat keberhasilan pembelajaran (Reza Aprilianto Mandala Putra, 2020).

Menurut Mulandini dkk.,( 2019) seprti ditulis Muhammad khoiruzzadi,Mabid Barokah dan Aisyatin Kamila, Perkembangan motorik pada anak usia dini bisa dibedakan menjadi dua yaitu motorik kasar dan motorik halus. Motorik kasar berkaitan dengan penggunaan otototot besar, dan kegiatannya dapat menguras energi seperti berlari, jalan- jalan, menari, dan sebagainya. Berbeda dengan motorik kasar, motorik halus hanya melibatkan otot kecil pada anak seperti kegiatan menyusun balok. Selain itu, untuk meningkatkan motorik halus pada anak juga bisa menggunakan metode proyek berbasis pendekatan saintifik (Muhammad khoiruzzadi, Mabid Barokah dan Asiyatin Kamila, 2020).

Untuk mengembangkan aspek kognitif pada anak, para guru menggunakan pendekatan kontekstual kepada anak baik anak yang perkembangan kognitifnya cepat atau lambat. Salah satu hal yang penting dalam kegiatan belajar mengajar adalah terpenuhinya sarana dan prasarana dalam mengembangan aspek kognitif anak, selain itu diperlukan metode yang tepat dalam mengajarkan anak khususnya yang berkaitan dengan kognitif anak seperti berhitung, menghafal, menulis, menggambar, mewarnai dan membaca. Selain pintar secara kognitif, anak juga harus bisa menerima dan diterima di lingkungan sekitarnya. Kemampuan sosial pada anak juga perlu dikembangkan dari sedini mungkin supaya anak tidak minder, pemalu, mau bergaul dengan temannya, mau berkomunikasi dengan temannya. 
Tarbiatuna, Vol. 1, No. 1, April 2021

(Muhammad khoiruzzadi, Mabid Barokah dan Asiyatin Kamila, 2020)

\section{METODE PENELITIAN}

Penelitian ini menggunakan design penelitian kualitatif dengan teknik wawancara guna memperoleh gambaran sistem pembelajaran pada tingkat Pendidikan Anak Usia Dini (PAUD) melalui media online pada masa pandemi dengan dilaksanakannya pembelajaran jarak jauh atau disebut juga belajar dari rumah.

Penelitian dilakukan Pada dua sekolah yaitu Raudhatul Athfal An-Nur yang berada di Kecamatan Leuwiliang, Desa Leuwiliang, Kp. Aman sari Rt 02/08 dan Raudhatul Athfal Darul Ihsan yang berada di Kecamatan Leuwiliang, Desa Karacak, Rt 03/02 ，Kp. Lebak Kaum. Penelitian dilakukan Selama 30 hari dari tanggal 01 agustus sampai tanggal 30 agustus 2020. Responden atau sumber data yang diperoleh dari 2 orang sebagai Kepala sekolah sekaligus guru dan 2 orang sebagai guru kelas dari 2 Raudhatul Athfal tersebut.

\section{HASIL PENELITIAN DAN PEMBAHASAN}

Pembelajaran di era covid tentunya sangat berbeda dan memberikan perubahan yang spesifik bagi pendidikan khususnya pada tingkat PAUD/Sederajat. Perubahan ini dirasakan oleh pendidik, Walimurid dan siswa pada sistem pembelajaran yang beralih menjadi Belajar dari rumah dengan menggunakan sistem daring/online.

\section{Efektivitas Pembelajaran PAUD} Online di Era Covid

a) Pentingnya Pembelajaran PAUD di Era Covid

Betapa pentingnya pendidikan untuk anak usia dini, yang pada usia inilah anak mengalami masa emas atau disebut dengan Golden Age karena pertumbuhan dan perkembangan anak sangat pesat.

Seperti pernyataan dari MNL "Penting banget karena kan anak PAUD itu masa emas atau golden age disebutnya jadi walaupun dimasa covid ini harus ada ilmu pengetahuan yang masuk kepada anak karena kesempatan ini walaupun via online anak tetap dapat kesempatan belajar". 
Tarbiatuna, Vol. 1, No. 1, April 2021

HA juga mengatakan "Sangat penting sekali, karena pada usia PAUD ini anak lebih cepat untuk menyerap pengetahuan"

Anak membangun pengetahuan sendiri, Sejak lahir anak diberi berbagai kemampuan. Dalam konsep ini anak dibiarkan belajar melalui pengalamanpengalaman dan pengetahuan yang dialaminya sejak anak lahir dan pengetahuan yang telah anak dapat selama hidup. Konsep ini diberikan agar anak dirangsang untuk menambah pengetahuan yang telah diberikan melalui materi-materi yang disampikan oleh guru dengan caranya sendiri. Anak diberikan fasilitas yang dapat menunjang untuk membangun pengetahuannya sendiri ( Tatik Ariyanti, 2016)

Seperi pernyataan dari Mf "Sangat penting saat anak berada di PAUD mereka akan di berikan sejumlah keterampilan yang sesuai dengan usianya, untuk perkembangan otak, sosial dan emosional dan anak pun akan lebih siap ketika melanjutkan ke jenjang berikutnya"

Walaupun dimasa pandemi, pembelajaran harus tetap dilaksanakan guna memberikan aktifitas kepada anak didik dalam memperoleh ilmu pengetahuan dan agar dapat tercapai tujuan pendidikan.

DS menyatakan bahwa "Karena ini masa darurat covid, pembelajaran harus tetap dilaksanakan untuk semua jenjang termasuk usia PAUD. Imi sudah menjadi keputusan Kementrian Pendidikan dengan mengikuti prosedur yang sudah disepakati baik itu tata cara, metode dan teknisnya, kita para pendidik tinggal mengikuti aturan tersebut",

b) Sistem Pembelajaran PAUD di Era Covid

Menurut Wicaksono (2020) seperti ditulis Renti Oktaria mengatakan, Belakangan Kementerian Pendidikan dan Kebudayaan, melalui video conference Abdoellah selaku Pelaksana tugas (Plt) Direktur Pembinaan Guru dan Tenaga Kependidikan PAUD telah mengingatkan agar guru Pendidikan Anak Usia Dini (PAUD) tak memberikan pekerjaan rumah (PR) kepada para siswanya yang melaksanakan belajar dari rumah darurat penanganan pandemi virus korona (Renti Oktaria, 2020). 
Tarbiatuna, Vol. 1, No. 1, April 2021

Salah satu solusi yang diberikan Kementrian Pendidikan dalam memutus rantai Virus

Conona (Covid-19) adalah dengan mengalihkan pembelajaran lanngsung disekolah menjadi pembelajaran jarak jauh yang dilakukan dirumah dalam semua jenjang pendidikan. Untuk pendidikan anak usia dini (PAUD) dalam melaksanakan pembelajaran dengan sistem belajar daring yaitu melalui media elektronik dan sistem belajar luring yang dimana diadakan pertemuan antara guru dan walimurid hanya untuk mengambil dan menyerahkan tugas anak yang penugasannya untuk beberapa hari.

Seperti yang dikatakan oleh HA dan Mf "Menggunakan sistem luring, daring dan tatap muka”

Seperti yang dikatakan oleh MNL "Menggunakan sistem daring yaitu dengan menggunakan aplikasi Whatsapp (WA) melalui pengiriman tugas misal videocall atau zoom tapi kebanyakan orang tua tidak semuanya punya hp untuk pembelajaran PAUD jadi guru hanya memberikan tugas meggunakan sistem $W A$ ”
Menurut DS “Sekolah harus mencarikan solusi bagi siswa ataupun orang tua untuk mengikuti pembelajaran online. Sekolah harus aktif ataupun inisiatif menanyakan apakah sanggup atau tidak para orang tua. Jangan sampai mereka memaksakan diri mengikuti pembelajaran online diluar kemampuan mereka khususnya secara ekonomi. Intinya sekolah harus peka bagaimana pembelajaran online ini jangan sampai membebani mereka”.

c) Aktifitas Belajar Online

Pembelajaran yang dilakukan via online memang sulit dilakukan pada jenjang Pendidikan Anak Usia Dini (PAUD), karena anak-anak belum memahami cara menggunakan media online dan belum mampu belajar secara mandiri. Pembelajaran anak harus tetap dalam pengawasan dan bimbingan orang tua dalam mengerjakan tugasnya dan mengirim hasil belajar anak.

Seperti pernyataan DS "Untuk pembelajaran PAUD ataupun TK dan sejenisnya pembelajaran online itu sangat sulit kenapa karena tidak efektif harus bertatap muka tapi karena covid, diwajibkan untuk pembelajaran online harus mengarah kepada edukasi artinya 
Tarbiatuna, Vol. 1, No. 1, April 2021

edukasi itu lebih banyak bentuk pembiasaan sehari-hari pelajarannya hanya sedikit saja lebih singkat lebih banyak kepembiasaan sehari-hari kenapa supaya anak-anak tidak jenuh dan tidak terbebani contohnya orang tua dan guru harus bekerja sama untuk memulai melakukan pekerjaan yang ringan-ringan dirumah mereka seperti mencuci tangan, merapikan tempat tidur, menyimpan mainan mereka atau menyimpan gelas piring setelah mereka makan itu untu penilaiannya orang tua memfoto atau memvideo kegiatan anak lalu diserahkan keguuru masing-masing”

Renti Oktaria dalam penelitiannya mengatakan bahwa "Kesepuluh orang tua menyatakan rasa prihatinnya dengan kondisi dimana sekolah anak mereka yang menerapkan model pembelajaran online, seperti dengan jenjang pendidikan yang ada di atasnya. Anak dituntut untuk memenuhi target belajar, sebagai implementasi kebijakan belajar di rumah, bahkan beberapa lembaga PAUD program TK telah memberikan tugas kepada anak usia dini dengan metode pengiriman laporan tugas secara daring atau melalui gawai, dengan aplikasi WAG orang tua atau aplikasi lainnya. Tujuh dari sepuluh orang tua menyampaikan pengalamannya yang harus membimbing anaknya dari Subuh hingga menjelang Isya hanya untuk memenuhi semua tugas yang diberikan oleh guru di sekolah" (Renti Oktaria, 2020)

Berbagai cara yang dilakukan untuk mempermudah komunikasi orang tua dengan guru dalam menginformasikan materi pembelajaran dan hasil belajar anak dengan banyak waktu luang tanpa meghambat aktivitas ataupun pekerjaan orang tua.

MNL mengatakan "Aktivitasnya sama seperti belajar disekolah yang membedakan hanya online saja jadi anak lebih banyak belajar dirumah bersama orang tua Cuma materi semua sama seperti disekolah dan pengiriman tugas juga ada jarak misal dikasih waktu sampai malam masih boleh mengirim tugas"

Seperti pernyataan Mf "Aktivis yang d lakukan dengan cara memberikan tugas via WA, atau menonton d TVRI"

HA mengatakan bahwa "Secara bergantian/ bergiliran"

d) Pengaruh Pembelajaran Online Selama Pandemi 
Tarbiatuna, Vol. 1, No. 1, April 2021

Azizah Nurul Fatah dalam penelitiannya mengatakan bahwa Tantangan lain yang dihadapi oleh lembaga PAUD dalam menerapkan kebijakan SFH adalah menghadapai karakteristik anak usia dini yang baru mulai memasuki dunia sekolah. Anak baru belajar bagaimana bersekolah dan masih beradaptasi dengan kehidupan sekolah. Selain itu, ada pula karakteristik anak usia dini yang masih sering moody, apalagi dalam hal belajar. Terkadang anak semangat bersekolah, kadang juga malas. Dapat dilihat bahwa motivasi belajar anak usia dini masih rendah dan masih membutuhkan bimbingan dan dorongan dari orang yang lebih tua, entah guru atau orangtua sebagai motivator atau penggeraknya. Oleh sebab itulah hal tersebut menjadi tantangan sendiri dalam hal motivasi belajar, apalagi melihat dalam kondisi penerapan kebijakan SFH yang kegiatan belajarnya dilakukan di rumah. Tanpa guru yang mendampingi serta teman-teman kelas yang biasanya menjadi teman belajar, tentu anak akan berkurang motivasi dan semangat belajarnya (Azizah Nurul Fatah,2020)

DS menyatakan bahwa "Pengaruh baik pada pembelajaran online/daring yaitu memudahkan pendidik dalam menyampaikan pembelajaran dan menambah nilai kemandirian dan pendewasaan individu. Adapun pengaruh negatifnya pembelajaran jadi tidak efektif karena jarak jauh, banyak siswa/orang tua yang tidak paham dengan mata pelajaran atau materi yang disampaikan melalui pembelajaran online dan guru lebih banyak memberikan tugas ketika pembelajaran online dibandingkan ketika dengan pembelajaran didalam kelas”,

MNL “Ada, pengaruhnya anak karena tidak disekolah jadi semangatnya kurang, terus mood nya mulai sedikit berkurang beda dengan disekolah, kalau disekolah itu karna dia banyak teman kalau dirumah hanya dengan orang tuanya jadi pengaruh keanaknya semangatnya beda gitu”,

Mf "Ada Salah satunya Anak kurang semangat mengikuti pelajaran online”

HA “Ada, pengaruh untuk orang tua: orang tua menjadi tau perkembangan anak nya seperti apa, sedangkan pengaruh untuk anak, anak tidak semangat untuk belajar",

e) Akibat Terhadap Kegiatan Belajar Mengajar (KBM) Secara Online 
Tarbiatuna, Vol. 1, No. 1, April 2021

Dari beberapa pengaruh yang dipaparkan diatas, dapat diketahui KBM yang dilakukan secara online ini menjadi tidak efektif dan efisien terhadap pembelajaran yang dilakukan, akibatnya pembelajaran tidak dapat diberikan guru dan didapatkan oleh siswa secara optimal. Semua Responden mengatakan KBM secara online tidak efektif dan efisien.

Miarso (2004) seperti ditulis Afifatu Rohmawati mengatakan bahwa, efektivitas pembelajaran merupakan salah satu standart mutu pendidikan dan sering kali diukur dengan tercapainya tujuan, atau dapat juga diartikan sebagai ketepatan dalam mengelola suatu situasi, "doing the right things" (Afifatu Rohmawati, 2015)

Seperti yang dikatakan MNL "Kalau menurut saya sih tidak efektif yaitu dari pembelajarannya guru sudah memberikan secara maksimal kepada anak misal dalam menyampaikan aspeknya seluruhnya tapi anak sulit/tidak menerima apa yang disampaikan oleh guru jadi kurang efektif kalau disekolah bisa diulang-ulanng berkali-kali tapi kalau dirumah kan guru hanya menyampaikan sekali kemudian kalau siswanya bertanya kepada anaknya gitu”

DS, Mf dan HA menyatakan hal yang sama bahwa "Pembelajaran online sangat tidak efektif karena metode daring/online tidak cocok untuk usia PAUD dan anak RA belum paham dengan pembelajaran online",

\section{Kendala Dan Solusi Pembelajaran Online}

Permasalahan yang sering kali menjadi faktor penghambat keberhasilan dari suatu kegiatan. Seperti halnya dalam KBM yang berlangsung via online ini menjadi kendala dalam proses pembelajaran yang dilakukan, salah satunya sulitnya jaringan internet atau signal.

Dalam penelitian Rizqon Halal Syah Aji, Kendala yang dialami dunia pendidikan Indonesia perlu mengikuti alur yang sekiranya dapat menolong kondisi sekolah dalam keadaan darurat. Sekolah perlu memaksakan diri menggunakan media daring. Namun penggunaan teknologi bukan tidak ada masalah, banyak varians masalah yang 
menghambat terlaksananya efektivitas pembelajaran dengan metode daring diantaranya adalah:

\section{Keterbatasan Penguasaan Teknologi} Informasi oleh Guru dan Siswa. Kondisi guru di Indonesia tidak seluruhnya paham penggunaan teknologi, ini bisa dilihat dari guru-guru yang lahir tahun sebelum 1980an. Kendala teknologi informasi membatasi mereka dalam menggunakan media daring. Begitu juga dengan siswa yang kondisinya hampir sama dengan guru-guru yang dimaksud dengan pemahaman penggunaan teknologi.

2. Sarana dan Prasarana yang Kurang Memadai. Perangkat pendukung teknologi jelas mahal. Banyak di daerah Indonesia yang guru pun masih dalam kondisi ekonominya yang menghawatirkan. Kesejahteraan guru maupun murid yang membatasi mereka dari serba terbatas dalam menikmati sarana dan prasarana teknologi informasi yang sangat diperlukan dengan musibah Covid-19 ini.

3. Akses Internet yang terbatas. Jaringan internet yang benar-benar masih belum merata di pelosok negeri. Tidak semua lembaga pendidikan baik Sekolah dasar maupun sekolah menengah dapat menikmati internet. Jika ada pun jaringan internet kondisinya masih belum mampu mengkover media daring.

4. Kurang siapnya penyediaan Anggaran. Biaya juga sesuatu yang menghambat karena, aspek kesejahteraan guru dan murid masih jauh dari harapan. Ketika mereka menggunakan kuota internet untuk memenuhi kebutuhan media daring, maka jelas mereka tidak sanggup membayarnya. Ada dilema dalam pemanfaatan media daring, ketika menteri pendidikan memberikan semangat produktivitas harus melaju, namun disisi lain kecakapan dan kemampuan finansial guru dan siswa belum melaju ke arah yang sama. Negara pun belum hadir secara menyeluruh dalam memfasilitasi kebutuhan biaya yang dimaksud (Rizqon Halal Syah Aji, 2020)

DS mengatakan yaitu "Kendala orang tua dan siswa yang pertama ketidaksiapan menerima peurbahan, kini orang tua menjadi guru atau selama anak belajar dirumah orang ttua harus mampu menjadi guru untuk anaknya. Kedua, perilaku anak berbeda (moody) karena situasi pandemi ini orang tua harus banyak bersabar menghadapi karena mood anak mudah berubah oleh karena 
Tarbiatuna, Vol. 1, No. 1, April 2021

itu orang tua dituntut untuk menjaga mood anak. Ketiga, komunikasi dengan guru terkait dengan tugas dan arahan belajar, orang tua juga harus menjaga komuniaksi dengan guru agar orang ua tetap mendapatkan panduan belajar dari rumah untuk anak. Ke enpat, ketersediaan perangkat elektronik informasi yang merupakan salah satu kendala yang dihadapi orang tua tentu karena tidak semua orang tua mempunyai aksesin dan tidak semua orang tua mahir menggunakan teknologi”,

DS juga menyatakan bahwa "Selain kendala yang disebutkan diatas, kendala terbesar yang dirasakan adalah kejenuhan maka orang tua harus kreatif dalam membangun interaksi dengan anak karena orang tua adalah sebagai wakil guru dirumahnya. Yaitu yang pertama membuat jadwal yang fleksibel bahwa anak sudah siap atau belum untuk belajar, kedua komunikasi yang terbuka dengan anak kita harus menerima keluhan atau kesulitan anak ketika belajar dirumah dengan metode daring, yang ketiga orang tua harus meluangkan waktu untuk membimbing menemani anak belajar karena tidak bisa mereka belajar sendiri dirumah dengan ketidak pahaman, kemudian keempat melindungi anak dari bahaya HP karena HP ini sangat tidak dianjurkan untuk anak usai PAUD jadi mereka harus dibimbing dan diarahkan untuk menggunakannya, kemudian yang kelima tetap berkomunikasi dengan guru bagaimana cara mengajarkan anak ketika belajar dirumah sehingga ada keselarasan ketika belajar dirumah dengan disekolah" ujarnya.

Menurut Hasanah (2015) seperti ditulis oleh Azizah Nurul Fatah, Lingkungan belajar harus diciptakan sepositif mungkin setara dengan lingkungan sekolah, agar motivasi belajar siswa dapat tumbuh. Bila lingkungan sekolah berkualitas tercipta serta motivasi belajar siswa tinggi, maka akan dapat meningkatkan hasil belajar peserta didik. Selain itu, Emda (2018:172-182) Menyatakan bahwa motivasi belajar baik intrinsik maupun ekstrinsik harus dimiliki siswa karena memiliki kedudukan yang sangat penting agar tujuan pembelajaran yang telah ditetapkan dapat tercapai, serta agar adanya motivasi tersebut dapat memberikan semangat kepada siswa sehingga ia dapat mengetahui arah belajarnya. Dari pemaparan tersebut dapat dilihat betapa pentingnya motivasi belajar 
Tarbiatuna, Vol. 1, No. 1, April 2021

dalam suatu proses pembelajaran. Adanya motivasi belajar harus diupayakan ada dalam diri siswa, dan bila ada hambatan diusahakan pula untuk diminimalisir. Sehingga hasil yang ingin dicapai sebagai hasil dari pembelajaran dapat diperoleh secara maksimal (Azizah Nurul Fatah, 2020)

Seperti yang dikatakan MNL "Kendalanya kayanya signal terus harusnya sih ngasih semangat juga supaya anak mau mengerjakan tugas dan motivasi”. Dan Solusi dalam mengatasi kendala tersebut MNL mengatakan "Kaya tadi ya Harus memberikan adanya interaksi sama anak misalnya ketemu satu minggu sekali, datang kerumah atau melakukan kelompok siswa jadi siswa itu masuk sekolah tapi di kelompokan supaya pembelajarannya efektif dan secara tatap muka langsung walaupun tidak sering tidak banyak gitu”

Menurut HA “Kendalanya anak sering malas belajar dan kebanyakan bermain, menurut nya belajar sendiri yang hanya di dampingi orang tua tidak semangat” dan "Solusinya memberikan anak pengarahan dengan bahayanya covid ini, dan motivasi agar ttap mau belajar walaupun dirumah"

Mf mengatakan bahwa “ ada, Masih ada yang tidak punya hp android, Tidak punya kuota, Susah sinyal dan Solusinya Orang tua datang kesekolah untuk mengambil LKA"

3. Upaya Guru Dalam Mengembangkan Pembelajaran PAUD Diera Covid

a) Pengembangan Aspek Pembelajaran PAUD

Guru PAUD dituntut untuk lebih kreatif dan inovatif dalam mengembangkan pembelajaran. Muhammad Khoiruzzadi, dkk dalam hasil penelitiannya mengatakan, Optimalisasi perkembangan kognitif, sosial dan motorik anak merupakan tugas dari seorang guru di sekolah. Guru perlu mengerti perkembangan ideal seorang anak dilihat dari aspek kognitif, sosial dan motoriknya. Untuk guru yang mengajar anak-anak yang masih berumur 4-6 tahun haruslah mengerti perkembangan tiap peserta didik. Karena pada usia tersebut merupakan usia yang masuk pada masa golden age, peran lingkungan di sekitar 
Tarbiatuna, Vol. 1, No. 1, April 2021

sangatlah menentukan termasuk guru dan teman sebaya di sekolah, orang tua di rumah dan teman bermain di lingkungan rumah. Tiap anak juga memiliki potensinya masing-masing baik dari ranah kognitif, sosial maupun motorik anak. Maka dari itu, Perlunya kerjasama yang baik antara guru di sekolah dan orang tua di rumah dalam mengoptimalkan perkembangan kognitif, sosial dan motorik anak (Muhammad Khoiruzzadi, $\mathrm{dkk}, 2020)$

MNL Mengatakan "Kalau itu misalnya dari aspek agama anak dibiasakan untuk sholat, moralnya juga orang tua memberikan contoh yang baik, motoriknya anak dirumah harus belajar menulis mewarnai, bahasanya anak diajarkan untuk cerita atau ngobrol bareng sama orang tua dengan bahasa yang baik, kognitifnya kalau dari guru memberikan sama dari sekolah materinya sama wlaupun disampaikan lewat online dan jika siswa ada yang tidak dipahami bisa bertanya keguru atau orang tua menyampaikan kembali dan orang tuapun harus bisa mengerti dalam menyampaikan kepada anak seperti pengetahuan anak”.
Pengembangan yang dilakukan DS sebagai berikut :

1. Moral/agama, meminta orgtua membiasakan membaca doa sehari2 saat melakukan kegiatan, mengajak solat berjamaah

2. Motorik = membiasakan memasang kancing baju sendiri, merapihkan mainan, memeras spon berisi air

3. Bahasa = mengajak anak bermain menyusun kata dan kalimat sederhana, membacakan anak cerita atau dgn mendongeng

4. Kognitif = anak diajak belajar menyelesaikan masalah yg paling sederhana

5. Sosial ekonomi = mengajarkan anak utk mandiri, percaya diri, belajar berinteraksi dan belajar mentaati peraturan

6. Seni = memggambar benda-benda yang ada dirumah dan diajak bernyanyi lagu anak-anak

Menurut Mf, pengembangan Pembelajaran dapat dilakukan dengan beberapa hal: 
1. Moral\&agama : pembiasaan salam, baca do'a, praktek shalat dan lainya

2. Motorik: Bermain balok, playdough, berolahraga dan lainya

3. Bahasa : Bercerita, bermain peran, bercakap, Dll

\section{Kog : Mengurutkan, mengelompok,dll}

5. Sosem: Sikap tanggung jawab,sabar menunggu giliran, percaya diri dll

\section{Seni : Kolase, mewarnai dll}

Namun HA menyatakan bahwa "Dengan cara memberikan video-video dan nyanyian melalui VN"

b) Berusaha Kreatif dan Inovatif dalam Pembelajaran PAUD

Guru merupakan salah satu orang yang sangat terdekat dengan anak didik setelah orang tua. Bahkan tidak sedikit anak yang lebih dekat dengan guru dan lebih sering menuruti perintah guru dibandingkan perintah orang tua. Oleh karena itu, guru memiliki posisi yang sangat strategis dalam mengupayakan perkembangan kreativitas anak didik. Disisin lain, guru juga merupakan motivator bagi anak didik. Dalam kegiatan

belajar-mengajar motivasi kepada anak didik merupakan daya penggerak dalam diri anak yang menimbulkan keinginan belajar yang mengara pada terwujudnya tujuan yang dikehendaki. Berikut ini adalah beberapa upaya guru dalam mengembangkan kreativitas anak diantaranya adalah melalui proses pembelajaran di sentra (Sartika M.Taher, 2019)

DS menyatakan "Upaya selalu dilakukan demi tercapainya kurikulum yg sudah ada, dengan terus berkomunikasi dengan para walimurid karena KBM online ini melibatkan para orang tua yang justru harus berperan aktif dlm pengajaran dirumah"

MNL menyatakan "Kalau anak PAUD itu lebih banyak seninya jadi dia harus penuh interaktif sama anak dimasa pandemi ini kita menunjukan semangat kepada anak terus upayanya tetap memberika pelajaran sesuai kemampua anak dan tidak memberatkan anak"

Mf berpendapat bahwa
"Memberikan kegiatan yang
menyenangkan dengan menggunakan
berbagai media, dengan sistem
berkelompok, Guru mengikuti berbagai


Tarbiatuna, Vol. 1, No. 1, April 2021

kegiatan pelatihan yang berkaitan dengan kegiatan PAUD"

\author{
HA mengatakan "Upaya yang \\ dilakukan memberikan tugas yang \\ menghasilkan suatu karya"
}

Dari pernyataan keempat responden diatas dapat disimpulkan bahwa Guru PAUD harus menciptakan suasana Pembelajaran Aktif, Inovatif, Kreatif dan Menyenangkan (PAIKEM). Walaupun di era covid, pembelajaran dari rumah tetaplah pembelajaran anak harus berkesan. Dan ke empat responden berharap agar pembelajaran dapat dilaksanakan normal kembali dengan tatap muka disekolah.

\section{SIMPULAN}

Pentingnya pembelajaran pada anak usai dini dapat meningkatkan perkembangan anak baik dalam pengetahuan, kemampuan dan dan sosianya. Walaupun diera covid, pembelajaran harus tetap disesuaikan dengan indikator dan prosedur yang sudah ada. Pembelajaran yang dilakukan menggunkan sistem pembelajaran online atau daring dan luring. Aktivitas pembelajaran online yang dilakukan menggunakan aplikasi WhatsApp dan media televisi dalam menyampaikan materi dan memberikan hasil belaja anak. Materi pelajaran tetap sama namun lebih mengarah pada edukasi yang artinya pembiasaan sehari-hari. Pembelajaran seperti ini memberi pengaruh positif yaitu memudahkan guru dalam menyampaikan materi dan orang tua dapat mengetahui perkembangan belajar anak, Namun berpengaruh negatif terhadap menurunnya motivasi belajar siswa. Akibatnya pembelajaran menjadi tidak efektif dan efisien karena Kegiatan belajar mengajar tidak berlangsung secara optimal, anak belum memahami pembelajaran online serta pembelajaran online tidak cocok untuk Pendidikan anak usia dini (PAUD).

Ketidaksiapan dalam menerima perubahan sistem pembelajaran menjadi kendala berlangsungnya proses $\mathrm{KBM}$ online. Diantaranya yaitu kejenuhan orang tua dan menurunnya motivasi belajar anak, kurangnya komunikasi guru dan orang tua, dan media elektronik sepeti handphone, kuota internet dan sulitnya signal. Solusinya yaiu Orang tua harus membimbing dan memotivasi anak agar 
Tarbiatuna, Vol. 1, No. 1, April 2021

semangat dalam belajar dan pembelajaran dilakukan secara luring.

Dalam mengembangkan aspek pembelajaran PAUD, guru menyesuaikan materi dan indikator pencapaiannya yang dapat mengembangkan potensi anak. Maka dari itu guru harus kreatif dan inovatif meningkatkan suasana belajar yang menyenangkan dan berkesan.

\section{DAFTAR PUSTAKA}

Ariyanti, T. (2016). Pentingnya Pendidikan Anak Usia Dini Bagi Tumbuh Kembang Anak The Importance of Childhood Education for Child Development. Dinamika Jurnal Ilmiah Pendidikan Dasar, 8(1).

CNNIndonesia.com, jakarta 16 maret 2020

CNNIndonesia.com, 31 maret 2020

Fadlilah, A. N. (2020). Strategi Menghidupkan Motivasi Belajar Anak Usia Dini Selama Pandemi COVID19 melalui Publikasi.
Jurnal Obsesi: Jurnal Pendidikan Anak Usia Dini, 5(1), 373-384. DOI: 10.31004/obsesi.v5i1.548

Firman, F., \& Rahayu, S. (2020). Pembelajaran Online di Tengah Pandemi Covid19. Indonesian Journal of Educational Science (IJES), 2(2), 81-89.

Pemenuhan Hak Anak Sejak Usia Dini. https://www.kpai.go.id

https://jdih.kemdikbud.go.id/suratedar $\underline{\text { anmenteri }}$

Khoiruzzadi, M., Barokah, M., \& Kamila, A. (2020). Upaya Guru Dalam

Memaksimalkan

Perkembangan Kognitif, Sosial dan Motorik Anak Usia Dini. JECED: Journal of Early Childhood Education and Development, 2(1), 40-51. DOI: https://doi.org/10.15642/je ced.v2i1.561 
Tarbiatuna, Vol. 1, No. 1, April 2021

Munastiwi, E. (2019). Peran Guru

Dalam Mengembangkan

Kreativitas Anak Usia Dini

Di TK Islam Terpadu

Salsabila Al-Muthi' in

Yogyakarta. GOLDEN

AGE: Jurnal Ilmiah

Tumbuh Kembang Anak

Usia Dini, 4(2), 35-50

Nahdi, K., Ramdhani, S., Yuliatin, R.

R., \& Hadi, Y. A. (2020).

Implementasi

Pembelajaran pada Masa

Lockdown bagi Lembaga

PAUD di Kabupaten

Lombok Timur. Jurnal

Obsesi: Jurnal Pendidikan

Anak Usia Dini, 5(1), 177-

186. DOI: 10.31004/

obsesi.v5i1.529

Nur, H. (2020). Hubungan Aktivitas

Penggunaan Teknologi

Untuk Pembelajaran

Pengembangan Oleh Guru

PAUD. PAUD Lectura:

Jurnal Pendidikan Anak

Usia Dini, 3(02), 28-39.

Oktaria, R., \& Putra, P. (2020). PENDIDIKAN ANAK
DALAM KELUARGA

SEBAGAI STRATEGI

PENDIDIKAN ANAK

USIA DINI SAAT

PANDEMI COVID-19.

Jurnal Ilmiah Pesona

PAUD, $\quad 7(1), \quad 41-51$.

https://ejournal.unp.ac.id/i

ndex.php./paud/index

Putra, R. A. M., \& Bangunan, P. V. K. Kendala Pelaksanaan Pembelajaran Jarak Jauh (PJJ) dalam Masa Pandemi https://www.researchgate.n et/publication/3409/7125

Rohmawati, A. (2015). Efektivitas Pembelajaran. Jurnal Pendidikan Usia Dini, 9(1), 15-32.

Sadikin, A., \& Hamidah, A. (2020). Pembelajaran Daring di Tengah Wabah Covid-19. BIODIK， 6(2)， 109-119. DOI:

https://doi.org/10.22437/bio . $\mathrm{v6i2.9759}$

Syah, R. H. (2020). Dampak Covid19 pada Pendidikan di Indonesia: Sekolah, 
Keterampilan, dan Proses

Pembelajaran. SALAM:

Jurnal Sosial Dan Budaya

Syar-I, 7 (5). DOI:

10.15408/sjsbs.v7i5.15314 